\title{
The Current Status of Exemption Clauses in the South African Law of Contract
}

\author{
Jean Chrysostome Kanamugire
}

Lecturer, Faculty of Law, Mafikeng Campus, North-West University

Email: jean.kanamugire@nwu.ac.za

\section{Terence Vincent Chimuka}

Legal Adviser, KwaZulu-Natal Department of Economic Development and Tourism, South Africa

Email: chimukat@kznded.gov.za

\section{Doi:10.5901/mjss.2014.v5n9p164}

\section{Abstract}

\begin{abstract}
Exemption clauses are used in contracts to exclude liability that ascribes to a contractant under normal circumstances. They are often incorporated in the standard form contracts by the service providers to the detriment of the other contracting party. As a general principle, exemption clauses are enforceable as they reflect an agreement between contracting parties. Exemption clauses that are contrary to public policy are invalid and unenforceable. They are often struck down by a court. Public policy nullifies agreements that are offensive in themselves. It is now rooted in the Constitution and the fundamental values it enshrines. They include human dignity, the achievement of equality, the advancement of human right, freedoms, non-racialism and non-sexism. Both Consumer Protection Act and National Credit Act have exclusion clauses in certain agreements to achieve fairness between contracting parties. Consumer Protection Act creates a general standard of fairness by listing a variety of prohibited terms and terms which are presumed to be unfair for the benefit of the consumers. National Credit Act also controls the exemption clauses in order to ensure or facilitate the fair, reasonable and valid conclusion of contracts. Exemption clauses are no longer the prerogative of the contracting parties. Sometimes, the exemption clauses in a contract need to be pointed out to the other party or consumer. The principles of fairness, reasonableness and constitutional values have to be considered when courts decide on the validity of exemption clauses. Consumer Protection Act, National Credit Act and Constitution have altered the use of exemption clauses in the law of contract to ensure fairness between contracting parties.
\end{abstract}

Keywords: Exemption clauses, standard form contracts, public policy, contractants, unequal bargaining power.

\section{Introduction}

Exemption clauses are used on a large scale in South Africa to exclude liability which attaches to a contractant under normal circumstances. ${ }^{1}$ They are not a modern creation and have been historically used under Roman-Dutch law. ${ }^{2}$ Exemption clauses are terms which are normally incorporated into standard form contracts to exclude a duty or liability which the law would otherwise attach to such a person. ${ }^{3}$ The use of exemption clauses has been historically frowned upon because they are excessively one sided and more often than not unfair on the other contracting party. Exemption clauses are in principle enforceable if they have been agreed upon by both contracting parties. An exemption clause, just like any other clause in a contract, can be struck down by a court if it is contrary to public policy. ${ }^{4}$ The courts have often employed different techniques of interpretation in dealing with exemption clauses. ${ }^{5}$ They have however not been able to deal with the problems posed by exemption clauses effectively and exemption clauses have continued to flourish at an alarming rate.

The legislature has intervened by enacting the Consumer Protection Act ${ }^{6}$ to deal with the unfairness which usually

\footnotetext{
1 See Afrox Healthcare Bpk v Strydom 2002 (6) SA 21 (SCA) 42 Brand JA, remarked that, in South Africa exemption clauses in standard contracts are the rule rather than the exception.

2 See De Groot Inl 3.14.12; Voet 21.1.10.

3 S, Van Der Merwe. Contract: General Principles 3ed (2007) 297; PN Stoop "The current status of the enforceability of contractual exemption clauses for the exclusion liability in the South African law of contract" (2008) 20 Merc LJ 496; L Steyn "The inclusion of 'additional' terms or 'standard terms and conditions' in a contract: the significance of the 'ticket' cases, caveat subscriptor and the application of the reliance theory" (2004) 16 SA Merc LJ 106.

${ }^{4}$ Afrox Healthcare Bpk v Strydom 2002 (6) SA 21 (SCA) at 34 the Supreme Court of Appeal held that a contract that is unfair to such an extent that it is contrary to public policy will not be enforced. See also S. Van Der Merwe. Contract: General Principles. 3rd ed. (2007) 298; Brisley v Drotsky 20024 SA 1 (SCA), paragraph 91.

5 See First National Bank of SA Ltd v Rosenblum 2001 (4) SA 189 (SCA); Johannesburg Country Club v Stott 2004 (5) SA 511 (SCA).

${ }^{6}$ Consumer Protection Act 68 of 2008.
} 
accompanies the use of exemption clauses in contracts. The Consumer Protection Act is not the only piece of legislation that has attempted to deal with the problems caused by exemption clauses; there are other pieces of legislation ${ }^{7}$ that have excluded the use of exemption clauses in certain agreements. Apart from legislation, the Constitution ${ }^{8}$ also has had an impact on the use and enforceability of exemption clauses. This article will critically discuss the use of exemption clauses under the common law and the various techniques of interpretation used by the courts in dealing with exemption clauses. It will further explore how the Consumer Protection Act, National Credit Act and other legislation have altered the common law position in relation to the use and enforceability of exemption clauses. The article will also briefly discuss the impact of the Constitution on the use and enforcement of exemption clauses.

\section{What is an Exemption Clause?}

An exemption clause is a term incorporated into a contract usually to exclude a contracting party's liability or a duty which under normal circumstances the law would attach in that type of agreement. In English law they are sometimes referred to as exclusionary clauses, exception clauses or disclaimers. ${ }^{9}$ According to Van Der Merwe, ${ }^{10}$ these terms exclude or limit liability of a contractant which is usually imposed by a naturalia of a contract. They are contractual terms that aim to limit, alter or exclude the liability, obligations or remedies of a contracting party. ${ }^{11}$ The exemption clauses concern any agreed deviation from the ruling law with regard to contractual or delictual liability that affects the rights, obligations, duties and procedural remedies normally emanating from a specific contract. ${ }^{12}$ They can serve a useful function, especially where they are applied as a planning instrument to achieve an acceptable spreading of risk inherent in a transaction. ${ }^{13}$ The exemption clauses are used by persons who run risk of incurring liability to others. ${ }^{14}$ An exemption clause, or even an entire contract that contains an exemption clause, may fail for lack of consensus between the contractants. ${ }^{15}$

Exemption clauses come in different forms, for example, a no representation clause which excludes the right of the other party to a contract to rescind a contract or claim for damages for misrepresentation which would have induced him to enter into a contract. ${ }^{16}$ Other exemption clauses can exclude liability for the breach of a warranty or a term of the contract e.g. a warrant for latent defects. Most exemption clauses are usually found in standard form contracts. ${ }^{17}$ The content of standard form contracts is usually fixed and determined unilaterally, and the other party then only has the choice of accepting the fixed contract terms in order to contract, so much so that freedom of contract is only a theoretical freedom comprising the decision whether one wishes to contract. ${ }^{18} \mathrm{~A}$ classic example of how an exemption clause is worded is found in First National Bank of SA Ltd $v$ Rosenblum ${ }^{19}$ (in a contract for the provision of a safe deposit box). It reads as follows: "The bank hereby notifies all its customers that while it will exercise every reasonable care, it is not liable for any loss or damage caused to any article lodged with it for safe custody whether by theft, rain, flow of storm water, wind, hail, lightning, fire, explosion, action of the elements or as a result of any cause whatsoever, including war or riot damage and whether the loss or damage is due to the bank's negligence or not."20

\section{Exemption Clauses for Specific Forms of Liability}

\subsection{A clause exempting a person against liability for breach of contract}

An exemption clause can be worded in a way which excuses a party to a contract to be excused from performing, in other

\footnotetext{
${ }^{7}$ National Credit Act 34 of 2005 and Alienation of Land Act 68 of 1981.

${ }^{8}$ Constitution of the Republic of South Africa, 1996.

${ }^{9}$ PN Stoop "The Current Status of the Enforceability of Contractual Exemption Clauses for the Exclusion of Liability in the South African Law of Contract" (2008) 20 SA Merc LJ 496.

${ }^{10}$ S, Van Der Merwe. Contract General Principles. 3rd ed. (2007) 297.

11PN Stoop "The Current Status of the Enforceability of Contractual Exemption Clauses for the Exclusion of Liability in the South African Law of Contract" (2008) 20 SA Merc LJ 496.

12 Ibid.

${ }^{13}$ See RH Christie The law of contract in South Africa $6^{\text {th }}$ ed. (2011)190.

14 lbid at page 191.

15 See Allen v Sixteen Stirling Investments (Pty) Ltd 1974 (4) SA 164 (D); Du Toit v Atkinson's Motors Bpk 1985(2) SA 893 (A).

${ }^{16}$ Section $51(1)(g)$ of the Consumer Protection 68 of 2008 prohibits such a clause in consumer agreements.

17 PN Stoop "The Current Status of the Enforceability of Contractual Exemption Clauses for the Exclusion of Liability in the South African Law of Contract" (2008) 20 SA Merc LJ 496. For a detailed definition of standard form contracts, see JC Kanamugire "The future of standard form contracts in South Africa with particular reference to recent developments in the law" (2013) 4 MJSS 335, 339-340.

$18 \mathrm{lbid}$.

19 First National Bank of SA Ltd v Rosenblum 2001 (4) SA 189 (SCA).

20 Ibid 194C-D.
} 
words an exemption clause can condone breach of contract or allow it. In English law a fundamental breach of a contract could not be covered by an exemption clause (doctrine of fundamental breach); however this doctrine has fallen into disuse in English law and has never been applied in South African law. ${ }^{21}$ In Elgin Brown and Hamer (Pty) Ltd v Industrial Machinery Suppliers (Pty) $L t d,{ }^{22}$ the court described the doctrine of fundamental breach as a question to the root of the contract and was relevant on whether there was a right to rescission but that fundamental breach had no bearing to the construction of exemption clause and could not govern its compass. According to Christie ${ }^{23}$ the case of Elgin means that there is no law forbidding an exemption clause from exempting consequences of fundamental breach. What is important is whether the wording of the clause is sufficient enough even to cover such breach. ${ }^{24}$ The Consumer Protection Act does not allow a person to contract out of liability for breach of contract. ${ }^{25}$

\subsection{A clause exempting a person against liability for latent defects}

Under the common law, a seller can expressly exclude certain forms of liability or include voetstoots clauses and this would result in the seller not liable unless they acted fraudulently. ${ }^{26} \mathrm{~A}$ voetstoots sale means that the purchaser accepts responsibility for any disease or defects in the property. ${ }^{27}$ It is usually the case where the sellers contract out of their obligations by undertaking to sell the thing as it stands or with all its faults. ${ }^{28}$ This position has been changed by the Consumer Protection Act; a voetstoots clause is now subject to certain limitations. ${ }^{29}$

\subsection{A clause exempting a person against liability for negligence}

An exemption clause can be relied on by a party to a contract where there has been a breach of contract due to negligence; even exclusion of liability for gross negligence can be covered by an exemption clause. ${ }^{30}$ In Afrox Healthcare Bpk $v$ Strydom, ${ }^{31}$ Brand JA accepted an exemption clause absolving a private hospital from liability for harm caused negligently to patients. The court was not convinced by the argument brought by the plaintiff that the clause was contrary to public policy and that it offends constitutional provisions especially the right to healthcare..$^{32} \mathrm{It}$ is also enough to cover negligence without spelling out precisely what harm is covered. However the court in Johannesburg Country Club $v$ Stott ${ }^{3}$ did not decide on whether a person can contract out of liability for negligently causing the death of another person, but seemed to suggest that it would be unlikely that such a clause can withstand constitutional scrutiny especially considering the sanctity of human life. The Consumer Protection Act allows parties to contract out of liability for ordinary negligence but prohibits gross negligence. ${ }^{34}$

\subsection{A clause exempting a person for fraud or dishonesty}

What is clear is that a person cannot escape liability for fraud or dishonesty by inserting an exemption clause to cover such conduct. ${ }^{35}$ Any party which purports to exempt fraud will be void because it would be offensive only to the extent that it condones and helps a person to be exempted for fraud. The Consumer Protection Act does not allow a party to a consumer agreement to contract out of liability for fraud or dishonesty. ${ }^{36}$

\footnotetext{
${ }_{21}$ RH Christie The law of contract in South Africa 6it ed. (2011)193.

22Elgin Brown and Hamer (Pty) Ltd v Industrial Machinery Suppliers (Pty) Ltd 1993 (3) SA 424 (A) 430I-J.

${ }^{23}$ RH Christie The law of contract in South Africa 6 th $^{\text {e }}$ ed. (2011)193.

${ }^{24}$ RH Christie The law of contract in South Africa 6"t ed. (2011)193.

25 See Regulation 44(3)(b) of the Consumer Protection Act regulations.

${ }^{26}$ D McQuoid-Mason Consumer law in South Africa (1997) 40.

${ }^{27} \mathrm{lbid}$.

${ }^{28}$ See Freddy Hirsch (Pty) Ltd v Chickenland (Pty) Ltd 2011(4) SA 276 (SCA).

${ }^{29}$ See Section 55 (6) of the Consumer Protection Act 68 of 2008.

30 In Essa v Divaris 1947 (1) SA 753 (A) shows that the Appellate Division accepted this as trite law; see also Central SAR v Adlington \& Co 1906 TS 964.

${ }^{31}$ Afrox Healthcare Bpk v Strydom 2002 (6) SA 21 (SCA).

32 lbid.

33.Johannesburg Country Club v Stott 2004 (5) SA 511 (SCA) 518-519.

${ }^{34}$ See Section 51(1)(c)(i).

${ }^{35}$ See Wells v SA Alumenite Co 1927 AD 69 at72, Innes CJ stated that "On grounds of public policy the law will not recognise an undertaking by which one of the contracting parties binds himself to condone and submit to the fraudulent conduct of the other. The courts will not lend themselves to the enforcement of such a stipulation; for to do so would be to protect and encourage fraud."

${ }^{36}$ See Section 51(a)(ii) and (iii).
} 


\section{The Interpretation of Exemption Clauses}

\subsection{Public policy}

Exemption clauses, like any other contractual clause, are generally legal, and this means that their enforcement in certain circumstances has led to harsh and unfair consequences. ${ }^{37}$ Although exemption clauses are legal, the courts are often inventive in limiting or excluding the ambit of their application when interpreting them in contracts. ${ }^{38}$ One of the basis upon which the courts determine whether or not an exemption clause is permissible when interpreting the contract is public policy. ${ }^{39}$ In Morrison v Angelo Deep Gold Mines Ltd, ${ }^{40}$ Innes CJ said: "Now it is a general principle that a man contracting without duress, without fraud, and understanding what he does, may freely waive any of his rights. There are certain exceptions to that rule, and certainly the law will not recognize any arrangement which is contrary to public policy."41 Public policy has now been described by the Supreme Court of Appeal in Brisley v Drotsky, ${ }^{42}$ Cameron JA stated that: "In its modern guise 'public policy' is now rooted in our Constitution and the fundamental values it enshrines. These include human dignity, the achievement of equality and the advancement of human rights and freedoms, nonracialism and non-sexism." 43 This principle was confirmed by the Constitutional Court in Barkuizen v Napier. ${ }^{44}$

\subsection{Restrictive interpretation}

The most popular method or technique has been restrictive interpretation by the courts to confine exemption clauses within reasonable bounds. ${ }^{45} \mathrm{McNally}$ JA, in Transport and Crane Hire Ltd v Hubert Davies \& Co Ltd, ${ }^{46}$ best described the technique of restrictive interpretation as: 'This weapon was called 'the true construction of the contract.' They used it with great skill and ingenuity. They used it so as to depart from the natural meaning of the words of the exemption clause and to put on them a strained and unnatural construction. In case after case, they said that the words were not strong enough to give the big concern exemption from liability, or that in the circumstances the big concern was not entitled to rely on the exemption clause...."47

It is competent for a court to interpret a clause narrowly where the language used is ambiguous. ${ }^{48}$ In First National Bank of South Africa Ltd v Rosenblum and Another, 49 the court reasoned that, where a party to a contract wishes to be exempted from an obligation which would normally attach had the contract been covered by the common law, then he has to clearly state his intention without any ambiguity. Marais JA stated that:

In matters of contract the parties are taken to have intended their legal rights and obligations to be governed by the common law unless they have plainly and unambiguously indicated the contrary. Where one of the parties wishes to be absolved either wholly or partially from an obligation or liability which would or could arise at common law under a contract of the kind which the parties intend to conclude, it is for that party to ensure that the extent to which he, she or it is to be absolved is plainly spelt out 50

However the court can only use this technique where the language used in an exemption clause is ambiguous and if not then the court is bound to enforce such a clause. In Walker $v$ Rednose ${ }^{51}$ the court refused to use the "proper approach' as the narrow interpretation is usually termed because the language of the clause exempted liability in express and unambiguous terms and that had to be given effect to.

\footnotetext{
${ }_{37}^{37}$ See generally Durban's Water Wonderland (Pty) Ltd v Botha 1999 (1) SA 982 (A); wells v SA Aluminite 1927 AD 69 at 73.

${ }^{38}$ See CC Turpin "Contract and imposed terms" (1956) 73 SALJ 144.

${ }^{39}$ Morrison v Angelo Deep Gold Mines Ltd 1905 TS 775 at 784-785 had this to say about the notion of Public Policy 'Now in our law it is a principle that agreements contra bonos mores will not be enforced, and that is in reality the same as the English maxim as to contracts against public policy. It is a wide-reading principle.....to succeed on the ground of public policy it must be shown that the arrangement necessarily contravenes or tends to induce contravention of some fundamental principle of justice or of general statutory law, or that it is necessarily to the prejudice of the interests of the public.'

40 Morrison v Angelo Deep Gold Mines Ltd 1905 TS 775.

${ }^{41}$ Ibid 779.

42 Brisley v Drotsky 2002 (4) SA 1 (SCA).

43 lbid paragraph 91.

44 Barkuizen v Napier 2007 (7) BCLR 691 (CC), paragraph 29

${ }^{45}$ See Johannesburg Country Club v Stott 2004 (5) SA 511 (SCA) 516D-I.

46 Transport and Crane Hire Ltd v Hubert Davies \& Co Ltd 1991 (4) SA 150 (ZS).

47 Ibid 160 - 162 cited from George Mitchell (Chesterhall) Ltd v Finney Lock Seeds Ltd 1983 QB 284, 296-6.

${ }^{48}$ See Anglo-Saxon Petroleum Co Ltd v Adamastos Shipping Co Ltd 1957 (2) QB 233 (CA) at 269 Denning LJ reflected the judiciary's attitude towards exemption clauses, he stated that "We have repeatedly refused to allow a party to a contract to escape from his just liability under it by reason of an exempting clause, unless he does so by words which are perfectly clear, effective and precise."

49 First National Bank of South Africa Ltd v Rosenblum and Another 2001 (4) SA 189 (SCA).

50 Ibid 195.

${ }^{51}$ Walker v Rednose 2007 (3) SA 514 (SCA) Paragraph 19-20.
} 
In interpreting restrictively the courts also often use the contra preferentum rule. ${ }^{52}$ In Drifters Adventure Tours $v$ Hircock, ${ }^{53}$ the court held that indemnity provisions in general should be construed restrictively and in a case of doubt, an exemption clause reasonably capable of bearing more than one meaning should be given the interpretation least favourable and biased against the maker. In Durban's Water Wonderland (Pty) Ltd v Botha, ${ }^{54}$ Scott JA stated that:" if the language of the disclaimer or exemption clause is such that it exempts the proferens from liability in express and unambiguous terms, effect must be given to the meaning. If there is ambiguity, the language must be construed against the proferens." 55

Apart from using public policy as a basis upon which exemption clauses can be struck down, the courts generally tend to find a way to circumvent the intended effect of exemption clauses because such clauses are viewed as unfair and draconian. ${ }^{56}$ In Mercurius Motors $v$ Lopez, ${ }^{57}$ Navsa JA stated that an exemption clause such as one that undermines the very essence of the contract "should clearly and pertinently be brought to the attention of the customer who signs a standard form contract." 58 The Supreme Court of Appeal came to a similar conclusion in the case of Freddy Hirsch (Pty) Ltd $v$ Chickenland (Pty) Ltd ${ }^{59}$ where the court stated that exemption from liability for latent defects do not apply to situations where a different article is delivered than that which was ordered because this constitutes non -performance.

\section{Judicial Limitation in Dealing with Exemption Clauses}

Exemption clauses have continued to operate to the detriment of most people despite the efforts of the courts. The courts cannot interfere with exemption clauses if the language is clear enough to be given its clear meaning. There are various reasons for the continued prevalence of exemption clauses. Firstly, the law of contract in South Africa has always assessed the validity of a contract or contractual provisions by applying the principle of legality and contractual interpretation. ${ }^{60}$ Contractual values and principles have prevailed over the need to achieve fairness between the parties. ${ }^{61}$ Even public policy, which is the tool through which the courts use to limit the effects of exemption clauses, has its own limitations. ${ }^{62}$ In Morrison v Angelo Deep Gold Mines Ltd, ${ }^{63}$ the court reflected how public policy had not been able to effectively deal with unfair exemption clauses. Mason J observed the exemption clauses and stated that "....to succeed on the ground of public policy it must be shown that the arrangement necessarily contravenes or tends to induce contravention of some fundamental principle of justice or of general statutory law, or that it is necessarily to the prejudice of the interests of the public." 64

Secondly, the principle of Pacta Sunt Servanda (which means "agreements should be enforced") has been the primary yard stick in interpreting contractual terms and the notion that a party is under no legal duty to inform the other party about the content of the proposed contract meant that documents containing onerous exemption clauses continued to operate against the other party to the contract with impunity. 65 The belief has always been that contracts that are freely entered into are sacred and should not be interfered with. ${ }^{66}$ The relative bargaining power of the contracting parties is considered material. ${ }^{67}$ The courts will, with only limited exceptions, protect and hold inviolable that which is contained

\footnotetext{
52 The rule means that the document is interpreted in favour of the party not represented for the drafting of the agreement.

${ }^{53}$ Drifters Adventure Tours v Hircock 2007 (2) SA 83 (SCA) at 87E-G.

54 Durban's Water Wonderland (Pty) Ltd v Botha 1999 (1) SA 982 (SCA).

55 Ibid 989G-J.

56 CJ Pretorius "Exemption Clauses and Mistake: Mercurius Motors v Lopez 2008 (3) SA 572 (SCA)" (2010) 73 THRHR 491.

57 Mercurius Motors v Lopez 2008 (3) SA 572 (SCA).

58 Ibid paragraph 33.

59 Freddy Hirsch (Pty) Ltd v Chickenland (Pty) Ltd 2011 (4) SA 276 (SCA) at paragraph 23.

60 Innes CJ in Wells v South African Alumenite Co 1927 AD 69 stated that '....no doubt the condition is hard and onerous; but if people sign conditions they must, in the absence of fraud, be held to them. Public Policy so demands'.

${ }^{61}$ Smalberger JA in Sasfin (Pty) Ltd v Beukes 1989 (1) SA 1 (A) 9B-F stated that 'The power to declare contracts against public policy should,...be used exercised sparingly and only in the clearest of cases...... it must be born in mind that public policy generally favours the utmost freedom of contract, and requires that commercial transactions should not be unduly trammeled by restrictions on that freedom.'

62 See Printing Registering Co v Sampson (1875) LR 19 EQ 462 at 465 Jessel MR stated that "If there is one thing which more than another, public policy requires, it is that men of full age and competent understanding shall have the utmost liberty of contracting and that their contracts, when entered freely and voluntarily, shall be held sacred and shall be enforced by courts of justice."

${ }^{63}$ Morrison v Angelo Deep Gold Mines Ltd 1905 TS 775.

64 Ibid 779 .

${ }_{65}$ See Afrox Healthcare Bpk $v$ Strydom supra at paragraph 34 and 35. The court held that a person who signs a written agreement without reading it does so at their own risk and will consequently be bound by the terms set out in that agreement as if they expressly agreed to them.

66 The ingredients of the doctrine of freedom of contract and sanctity of contract have been received by our courts from the much-quoted decision of Printing and Numerical Registering Company v Sampson (1875) LR 19 EQ 582 in which Sir Gorge Jessel MR stated that "if there is one thing which more than another public policy requires it is that men of full age and competent understanding shall have the utmost liberty of contracting and that their contracts when entered into freely and voluntarily shall be held sacred and shall be enforced by the courts of justice."

${ }_{67}$ See Grinaker Construction v Transvaal Provincial Administration 1982 (1) SA 312 (A) where Viljoen JA stated that "If the plaintiff has struck a bad bargain, the court cannot, out of sympathy for him, amend the contract in his favour."
} 
within the four corners of the signed contract as conclusive proof of the consensus of the parties. 68

Thirdly, freedom of contract meant that the courts were reluctant to interfere with contracts which were concluded validly between private citizens. In Burger v Central South African Railways ${ }^{69}$ Innes CJ held that "....our law does not recognise the right of a court to release a contracting party from the consequences of an agreement duly entered into by him merely because that agreement appears to be unreasonable."70

Fourthly, it is a requirement of a valid contract that both parties reach consensus. However in most contracts true consensus is seldom reached especially in standard contracts where the contracts are concluded on a take it or leave it basis. ${ }^{71}$ The result is that co-contractants in a weaker bargaining position will be exploited by their counterparts in stronger bargaining position. ${ }^{72} \mathrm{It}$ is unfortunate that in some instances where there is no actual consensus the courts have failed to protect the party who did not intend to be bound by the terms to which he or she signed. ${ }^{73}$ The effect this has had is that exemption clauses which are generally harsh have continued to operate to the detriment of the other party to the contract.

Fifth and lastly, extensive statutory control over unfair exemption clauses has become the norm in many overseas jurisdictions and South Africa had been lagging behind in this regard. ${ }^{74}$ As a result the Law Reform Commission proposed the Control of Unreasonable, Unconscionableness or Oppressiveness in Contracts or Terms Act. ${ }^{75}$ The proposed legislation by the Law Reform Commission was aimed at dealing with unfair contract terms a category that most exemption clauses belong. However this did not come to fruition and South Africa remained without statutory control of unfair contracts terms in general and exemption clauses in particular until the enactment of the Consumer Protection Act.

\section{An Overview of the Consumer Protection Act 68 of 2008}

The Consumer Protection Act is wide in its application. It applies to every transaction which occurs in South Africa unless it is exempted. ${ }^{76}$ It applies to the supply of goods and services and the promotion of such goods and services unless excluded. ${ }^{77}$ The meaning of the words "occurring within the South Africa" is uncertain because in some instances it is difficult to ascertain whether a transaction has taken place in the Republic especially with the prevalence of internet transactions that requirement could be problematic to enforce. ${ }^{78}$

The Act however excludes a number of transactions from its scope of application such as transactions which involve the supply or promotion of goods or services to the state, ${ }^{79}$ transactions which the consumer is a juristic person whose asset value or annual turnover at the time of the transaction is equal to or exceed the threshold to be determined by the minister in terms of section 6,80 transactions that have been exempted by the minister in terms of sections $5(3)$ and $5(4),{ }^{81}$ transactions that constitute agreements under the National Credit Act, but the goods and services that are subject of the credit agreement are not excluded from the ambit of the Act, ${ }^{82}$ transaction pertaining to services to be supplied under an employment contract (the logic being that the Labour Relations Act already regulates such), ${ }^{83}$ transactions giving effect to a collective bargaining agreement ${ }^{84}$ in terms of the Constitution ${ }^{85}$ and the Labour Relations Act ${ }^{86}$ or a

\footnotetext{
${ }^{68}$ E Van Eeden A guide to the Consumer Protection Act (2009)69.

${ }^{69}$ Burger v Central South African Railways 1903 TS 571.

70 Ibid 576.

71 See generally Durban Wonderland (Pty) Ltd v Botha 1999 (1) SA 982 (SCA).

72 PN Stoop "The Current Status of the Enforceability of Contractual Exemption Clauses for the Exclusion of Liability in the South African Law of Contract" 200820 SA Merc LJ 497.

${ }^{73}$ George v Fairmead (Pty) Ltd 1958 (2) SA 465 (A) at 472 the court held that "when a man is asked to put his signature to a document he cannot fail to realise that he is called upon to signify, by doing so, he assents to whatever words appear above his signature".

74 T Naude and G Lubbe 'Exemption Clauses- A Rethink Occasioned by Afrox Healthcare Bpk v Strydom' (2005) 122 SALJ 441.

75 South African Law Reform Commission Report on' Unreasonable Stipulations in Contracts and the Rectification of Contracts' Discussion Paper 65 (Project 47, 1998).

76 Consumer Protection Act 68 of 2008, s 5(1)(a), subsection 2, 3 and 4 allows for certain transactions to be exempted.

77 S 5(1)(b).

${ }^{78}$ W Jacobs, PN Stoop \& R Van Niekerk "Fundamental consumer rights under the consumer Protection Act: a critical overview and analysis" (2010) 13 PELJ 309.

${ }^{79} S$ 5(2)(a). The definition of state is not provided in the Act, it is therefore unclear whether companies which the state has shares are included? The definition of "Organ of state" is provided for in the Act with reference to section 239 of the constitution.

$80 S 5(2)(b)$. Section 6 gives the minister the power to determine the threshold which currently stands at $R 3$ million.

$81 S 5(2)(c)$.

82 S 5(2) (d). ML Du Preez is of the view that "To the extent that the bill may apply to credit agreements, it is bound to create confusion, unnecessary delays and litigation as a result of discrepancies/inconsistencies between the bill and the National Credit Act" in "The Consumer Protection Bill: A Few preliminary comments" TSAR (2009) 79.

$83 S 5(2)(e)$.

$84 S 5(2)(f)$.

${ }^{85} S 23$ of the Constitution.

${ }^{86} 66$ of 1995 .
} 
collective agreement as defined in the Labour Relation Act. ${ }^{87}$

The Consumer Protection Act arrogates a variety rights to consumers namely; the right to equality in the consumer market, ${ }^{88}$ right to privacy, ${ }^{89}$ right to choose, ${ }^{90}$ right to disclosure and information, ${ }^{91}$ right to fair and responsible marketing, ${ }^{92}$ right to fair and honest dealing, ${ }^{93}$ right to fair value, good quality and safety ${ }^{94}$ and the right to fair, just and reasonable terms and conditions. ${ }^{95}$ Exemption Clauses are classified under the right of consumers to fair, just and reasonable terms and conditions. ${ }^{96}$

\section{Incorporation of Exemption Clauses into Contracts}

\subsection{The common law incorporation rules}

The common law has certain requirements or rules of incorporating exemption clauses into contracts. The exemption clauses have to be agreed upon. ${ }^{97}$ Generally where the contractant is aware or reasonably ought to be aware that the other party is labouring under some or other misconception, he or she is under a duty to speak and inquire so as to clear the misapprehension. In Mercurius Motors $v$ Lopez, ${ }^{98}$ the court articulated an important rule of incorporating an exemption clause into a contract. Navsa JA held that a clause which could not be reasonably expected to be part of such a contract should be drawn to the attention of the other party to the contract. The court stated that:

An exemption clause such as that contained in clause 5 of the conditions of contract, that undermines the very essence of the contract of deposit, should be clearly and pertinently brought to the attention of a customer who signs a standard instruction form, and not by way of an inconspicuous and barely legible clause that refers to the conditions on the reverse side of the page in question ${ }^{99}$

Another important rule of incorporation was stipulated in Fourie $v$ Hansen, ${ }^{100}$ where Blieden $\mathrm{J}$ held that an exemption clause should be specifically brought to the attention of the person signing the document which contains an exemption clause. The court stated that the concerned clause should have at least been printed in a different colour ink, or underlined or printed in another font size to draw the attention of the reader. ${ }^{101}$ In Jacobs v Imperial Group (Pty) Ltd ${ }^{102}$ the court held that "the answer depends upon whether in all the circumstances the appellant did what was 'reasonably sufficient' to give patrons notice of the terms of the disclaimer." 103 A clear indication of another rule of incorporation under the common law is reflected by the case of Anglo-Saxon Petroleum Co Ltd v Adamastores Shipping Co Ltd where Denning LJ stated that: "We have repeatedly refused to allow a party to a contract to escape from his just liability under it by reason of an exempting clause, unless he does so by words which are perfectly clear, effective and precise."104

\subsection{Incorporation rules under the Consumer Protection Act 68 of 2008}

The Consumer Protection Act has codified common law rules of the incorporation of exemption clauses. ${ }^{105} \mathrm{~A}$ supplier who seeks to incorporate an exemption clause into a consumer agreement is supposed to meet the requirements set out

\footnotetext{
87 S 213 of Act No 66 of 1995.

88 Part A -sections 8-10 of the Consumer Protection Act.

${ }^{89}$ Part B-sections 11-12 of the Consumer Protection Act.

90 Part C-sections 13-21 of the Consumer Protection Act

${ }^{91}$ Part D-Sections 22-28 of the Consumer Protection Act.

92 Part E-Sections 29-39 of the Consumer Protection Act.

93 Part F-Sections 40-47 of the Consumer Protection Act.

${ }_{94}$ Part $\mathrm{H}$ - Sections 53-61 of the Consumer Protection Act.

${ }_{95}$ Part G- Sections 48-52 of the Consumer Protection Act. See also D McQuoid-Mason "Hospital exclusion clauses limiting liability for medical malpractice resulting in death or physical or psychological injury: what is the effect of the Consumer Protection Act?" (2012) 5 SAJBL 65,66.

${ }_{96}$ See T Naude "The consumer's right to fair, reasonable and just terms under the new Consumer Protection Act in a comparative perspective" 2009 SALJ 519.

${ }_{97}$ D \& H Piping system (Pty) Ltd v Trans Hex Group Ltd \& Another 2006 (3) SA 593 (SCA).

${ }_{98}^{9}$ Mercurius Motors v Lopez supra.

99 Ibid paragraph 33.

${ }^{100}$ Fourie v Hansen 2000 (1) All SA 510 (W)

101 Ibid.

102 Jacobs v imperial group (Pty) Ltd 2010 (2) All SA 540 (SCA).

103 Ibid paragraph 9.

104 Anglo-Saxon Petroleum Co Ltd v Adamastores Shipping Co Ltd 19572 QB 233 (CA) 269: L Steyn "The inclusion of 'additional' terms or 'standard terms and conditions' in a contract: the significance of the 'ticket' cases, caveat subscriptor and the application of the reliance theory" (2004) 16 SA Merc LJ $106,110$.

${ }^{105}$ Consumer Protection Act 68 of 2008 , s 49 .
} 
in section 49 that are: 106

- The clause must be written in plain language;107

- The customer must be made aware of the implications of the clause, that is the manner and form that is likely to draw the attention of the consumer under the circumstances and also this should be done before the contract is carried out; ${ }^{108}$ and

- The consumer should be given an adequate opportunity in the circumstances to fully comprehend the clause. ${ }^{109}$

Section 49 therefore means that a consumer who signs an exemption clause is not bound by it unless the nature and effect was specifically drawn to his or her attention in a required manner and was given enough opportunity to understand it. ${ }^{110}$

Where exemption clauses relates to an activity or facility and could pose a risk of an unusual character or nature, ${ }^{111}$ or the risk posed is that which an ordinary alert consumer would not expect or contemplate under the circumstances ${ }^{112}$ or the risk posed could result in serious injury or death, ${ }^{113}$ the supplier under the circumstances will be required to draw specifically to the attention of the consumer the existence of such risk, and the nature and potential effect in the manner required by section 49; and to make the consumer sign or initial it or act in a manner which is consistent with her being aware of the existence of the exemption clause. ${ }^{114}$

The Consumer Protection Act seems to have codified the common law's rules of incorporation as expressed through case law.115 The Act now requires that the nature and effect of the provision be drawn to the attention of the consumer in a manner which is conspicuous to attract the attention of an ordinary alert consumer having regard to the circumstances. ${ }^{116}$ This is a major change from the common law requirements which only required a signature as a basis for liability. ${ }^{117}$ The Act places an obligation on the supplier to draw the nature and effect of the provision before entering into a transaction or agreement or before engaging in an activity or access to a facility. ${ }^{118}$ The consumer has to be given an adequate opportunity in the circumstances to receive and comprehend the provision or notice. ${ }^{119}$ It means that an exemption clause will not be enforceable without meeting the threshold of the above mentioned requirements. This has provided the courts with a weapon, equally as effective as restrictive interpretation, enabling them to refuse enforcement if the duty to point the clause to the other party has not been discharged. ${ }^{120}$

\section{Prohibited Exemption Clauses in Consumer Agreement under the Consumer Protection Act}

The Consumer Protection Act introduces sweeping changes and acts as a general legislation outlawing a variety of clauses (amongst which some exemption clauses are included) which would have been enforceable under the common law. Section 51 (1) has a list of prohibited terms or conditions where suppliers are not allowed to make a contract subject to these prohibited provisions whether in an indirect or direct way. ${ }^{121}$ This means that, if a person contracts using the prohibited terms, the contract or the terms will be null and void. The courts no longer have discretion as was the case under the common law where the parties were left at the mercy of judicial activism. The following are prohibited:

- A provision that misleads or deceives the consumer or that subjects the consumer to fraudulent conduct; ${ }^{122}$

$106 S 49$ of the Consumer Protection Act.

${ }^{107 S} 49$ (3). This section is to be read together with Section 22 which requires that a notice should be in the prescribed manner and in plain language. According to Section 22 (2) a document, notice or visual is in plain language if its content can be understood without undue effort having regard to- the context, comprehensiveness and consistency of the notice, document or visual representation; the organization, form and style of the notice, document or visual representation; the vocabulary, usage and sentence structure of the notice, document or visual representation; and, the use of any illustrations, examples, headings or other aids to reading and understanding.

108 S 49(4), a consumer is supposed to be informed of the consequences before he or she enters into an agreement.

$109 S 49(5)$.

110lbid.

$111 S 49$ (2) (a).

$112 S 49(2)(b)$.

$113 S 49$ (2) (c).

114 Ibid.

115 See Anglo-Saxon Ptroleum Co Ltd v Adamastos Shipping Co Ltd (1957) 2 QB 233 (CA) at 269.

${ }_{116} S 49$ (4) (a).

117 See Burger v Central South African Railways 1903 TS 571.

${ }_{118}$ Consumer Protection Act, S 49 (4) (b).

$119 S 49$ (5).

120 C-J Pretorius "Exemption Clauses and Mistake: Mercurius Motors v Lopez 2008 (3) SA 572 (SCA)" (2010) 73 THRHR 500.

${ }_{121} S 51(1)$.

122S 51(1)(a)(ii) and (iii). This is a codification of the common law, a person could not be exempted for fraud; see Wells supra. 
- A provision that directly or indirectly purports to (i) waive or deprive a consumer of a right in terms of the Act (ii) avoid a supplier's obligation or duty in terms of the Act, ${ }^{123}$

- A provision that (i) purports to exclude or limit the liability of a supplier of goods or services for any loss directly or indirectly attributable to the gross negligence of the supplier or any person acting for, or controlled by the supplier (ii) constitutes an assumption of risk or liability by the consumer for a loss contemplated in (i);:i24

- A provision that imposes an obligation on a consumer to pay damages to or otherwise assume risk of handling any goods displayed by the supplier; ${ }^{125}$

- A clause that falsely expresses an acknowledgement by the consumer that (i) before the agreement was made, no representations or warranties were made in connection with the agreement by the supplier or a person on behalf of the supplier or (ii) the consumer has received goods or services, or a document that is required by the Act to be delivered to the consumer; 126

- A provision which requires the consumer to forfeit any money to the supplier (i) if the consumer exercises any rights in terms of the Act (ii) to which the supplier is not entitled in terms of the Act or any other law; 127

In order to avoid rigidity and to allow for flexibility in the law, the legislature promulgated regulations to add to those clauses which are already prohibited (Section 51 ) by the Act. These clauses are presumed to be unfair until the party that inserted them into a contract proves that they are not. Regulation $44(3)^{128}$ of the Consumer Protection Act has certain exemption clauses (which we selected from a number of them in Regulation 44(3)) which are deemed to be unfair if the clause is inserted (into a contract) by the supplier:

- Excluding or limiting the liability of a supplier for the death of, or the personal injury caused to a consumer through an act or omission of that supplier (to be read together with section 61 of the Act). ${ }^{129}$

- Limiting, or having the effect of limiting the supplier's vicarious liability for its agents. ${ }^{130}$

- Excluding or hindering the consumer's right to take legal action or exercise any other legal remedy, including by requiring the consumer to take disputes exclusively to arbitration not covered by the Act or other legislation. ${ }^{131}$

- Imposing a limitation period that is shorter than otherwise applicable under the common law or legislation for legal steps to be taken by the consumer (including for the making of a written demand and the institution of legal proceedings. ${ }^{132}$

- Forcing the consumer to indemnify the supplier against liability incurred by it to third parties. ${ }^{133}$

The inclusion of these regulations is a major improvement from the common law where there were no identifiable terms to indicate unfair exemption clauses. It is important to note that the regulations allow for an extension of the list to allow for those situations which may exist at a later stage but were not contemplated by the legislature at the time of drafting both the Consumer Protection Act and the above mentioned regulations. The onus is on the person who inserted the clause to prove that it is fair.

\section{Adjudication of Exemption Clauses under the CPA}

The courts have been given far-reaching powers by the Act in dealing with unfair contract terms (exemption clauses). ${ }^{134}$ In court proceedings the Act requires where there is a transaction between a supplier and a consumer and a person alleging that an agreement, a term or condition of an agreement which is void in terms the Act, the court is allowed to make an order severing any part of the relevant agreement, ${ }^{135}$ provision or if possible alter the provision to the extent

${ }^{123} S$ 51(1)(b) (i)-(iv). This is a codification of the common law as stated by the cases of Afrox Healthcare Bpk v Strydom supra at paragraph 33; First National Bank of SA Ltd $v$ Rosenblum \& Another 2001(4) SA 189 (SCA) at paragraphs 24-7.

${ }^{124} \mathrm{~S} 51(1)(c)($ ii).

$125 \mathrm{~S} 51$ (1) (c) (iii)

$126 \mathrm{~S} 51(1)(g)$ (i)-(ii)

${ }^{127} \mathrm{~S} 51(1)(h)(i)-(i i)$.

${ }^{128}$ Regulation 44 (3) of the Consumer Protection Act 68 of 2008 Government Gazette No. 34180

129 Regulation 44 (3) (a). This issue was never decided under the common law but there was a suggestion that it could be contrary to public policy in Stott $v$ Johannesburg Country Club supra.

${ }_{130}$ Regulation 44(3)(d). This is a change from the common law which allowed exemption clauses which exempt vicarious liability for agents, see First National Bank of

SA Ltd v Rosenblum \& another Supra.

131 Regulation 44(3)(x).

${ }^{132}$ Regulation 44(3) (z). This means the supplier has to justify the inclusion of a time bar clause in a contract. A justified inclusion of a time-bar clause is stated in Napier

$\checkmark$ Barkhuizen 2007 (5) SA 323 (CC).

133 Regulation 44(3)(e).

134 S 52(4).

${ }^{135} S$ 52(4)(a) (i) (aa). 
required to make sure that it conforms to the Act if it is reasonable to do so having regard to the transaction, agreement, provision or notice as a whole. ${ }^{136}$ The court can declare invalid the entire agreement, provision or notice as from the date it comes into operation. ${ }^{137}$ The court is also entitled to make a further order which is reasonable under the circumstances with due regard to the agreement, provision or notice depending on what it is. ${ }^{138}$ The Act now empowers the court to make an order of invalidity where the incorporation requirements (see Section 49) have not been complied with, whereas under the common law it was discretionary and depended on the whim of the judge presiding over a case. This is massive step towards the elimination of exemption clauses as the courts have now been given wider powers than was the situation under the common law.

The impact of the Consumer Protection Act on exemption clauses is also made clear by its section 4 which requires that the court or tribunal adjudicating on a matter before it in terms of the Act to develop the common law as necessary as possible in order to improve the realisation and enjoyment of consumer rights. ${ }^{139}$ The section requires the court to be innovative and make orders that better advances, protects, promotes and assures the realisation by consumers of their rights. ${ }^{140}$ The section further requires where a provision can be construed to have more than one meaning, the court should prefer the meaning that promotes the spirit and the purpose of the Act. ${ }^{141}$ Section $4(4)^{142}$ more importantly states that where exemption clauses are concerned, the court is required to interpret any standard form contract or any other document prepared or published by or on behalf of the supplier to the benefit of the consumer. This clearly means any exemption clauses which are not in favour of the consumer will be interpreted to give rights to the consumer rather than deprive them. Section 4 (4) (a) and (b) requires that any ambiguity in a document to be interpreted and resolved to benefit the consumer and any restriction, limitation or deprivation of a consumer's rights to be limited to the extent that a reasonable person would contemplate or expect with due regard to the circumstances. This is a codification of the common law contra- preferentem rule and its inclusion gives certainty to the law.

The Consumer Protection Act further deters people from engaging in conduct which is contrary to the Act or calculated conduct to frustrate or defeat the purpose of the Act. ${ }^{143}$ Conduct that is unconscionable, misleading or deceptive or reasonably likely to mislead or deceive is prohibited. ${ }^{144}$ Misrepresentation is not allowed unless one has reasonable grounds to believe that the representation is true. ${ }^{145}$

\section{Other Restrictive Legislation on Exemption Clauses}

It is also apparent that there are some statutes which exclude the applicability of exemption clauses. ${ }^{146} \mathrm{~A}$ good example is the National Credit Act ${ }^{147}$ which regards certain types of exemption clauses as not being valid in credit agreements. According to Section 90 of the National Credit Act, a credit agreement must not contain an unlawful provision. ${ }^{148}$ The Act has a variety of provisions which are unlawful in a credit agreement. ${ }^{149}$

The National Credit Act invalidates the following exemption clauses: a provision of a credit agreement is unlawful if it purports to exempt the credit provider from liability for any act, omission or representation by a person acting on behalf of the credit provider ${ }^{150}$ or any guarantee or warranty that would, in the absence of such a provision, be implied in a credit agreement. ${ }^{151}$ The Act also states that a provision is unlawful if it expresses an acknowledgment by the consumer that before the agreement was made no representations or warranties were made by the credit provider in connection with the agreement, ${ }^{152}$ or expresses that the consumer received goods or services when they actually did not receive the goods or services. ${ }^{153}$ This is a major shift from the common law which relied on a signature as a basis for an enforceability of a contract. The National Credit Act comes as a welcome relief to credit seekers who were at the mercy of credit providers.

\footnotetext{
$136 S 52$ (4)(a)(i)(aa).

${ }^{137} S 52(4)(a)(i)(b b)$.

${ }^{138} S$ 52(4)(b).

$139 S 4$ (2) (a).

${ }_{140 S} 4$ (2)(b).

${ }^{141} S 4$ (3).

${ }^{142} S 4$ (4).

${ }^{143} S 4$ (5)(a).

${ }^{144 S} 4$ (5)(b).

${ }^{145 S} 4$ (5)(c).

${ }^{146} R D$ Sharrock. Business Transactions Law $8^{\text {th }}$ ed. (2011)586.

147 National Credit Act 34 of 2005.

${ }^{148}$ National Credit Act 34 of 2005; S 90 (1).

149 See $S 90$ of the National Credit Act 34 of 2005.

150National Credit Act 34 of 2005; S 90 (2) (g) (i).

${ }^{151}$ National Credit Act 34 of 2005; $S 90$ (2) (g) (ii).

${ }_{152}$ National Credit Act 34 of 2005; $S 90$ (2) (h) (i).

${ }^{153}$ National Credit Act 34 of 2005; $S 90$ (2) (h) (ii).
} 
Another Act of parliament which has had an impact on the use of exemption clauses is the Alienation of Land Act. ${ }^{154}$ Section 15(1)(b) and (c) of the Alienation of Land Act states that, "an agreement whereby a purchaser forfeits any claim in respect of necessary expenditure that he has incurred with or without the authority of the owner or seller of the land concerned, in regard to the preservation of the land or any improvement thereon, any improvement that enhances the market value of the land and that was effected by him on the land with express or implied consent of the said owner or seller or the liability of a seller to indemnify the purchaser against eviction is restricted or excluded and shall be of no force or effect." $" 155$ The exclusion of such a clause is an improvement to the common law position and prevents unjust enrichment.

\section{The Constitution and Exemption Clauses}

The Constitution has had an influence on the use and enforceability of contractual terms and exemption clauses in particular. ${ }^{156}$ Contractual clauses which are contrary to public policy are unenforceable. Public policy represents the legal convictions of the community and under the constitutional dispensation, the Constitution is the most reliable statement of public policy available. ${ }^{157}$ The Constitutional Court had a chance to decide on the enforceability of a time bar clause (a specific type of an exemption clause) in an insurance contract in the case of Barkhuizen v Napier. ${ }^{158}$ The court stated that there are two questions to be asked in determining fairness, namely whether the clause is reasonable or not and if the clause is reasonable whether it should be enforced in the light of the circumstances. ${ }^{159}$ The court stated that the first question involved weighing up of two considerations which were public policy, as informed by the constitution, required in general that parties should comply with contractual obligations that have been freely and voluntarily undertaken (Pacta Sunt Servanda) and the other consideration was that all persons had the right to seek judicial redress. ${ }^{160}$ The court indicated that the second question involved an inquiry into the circumstances that prevented compliance with the clause. ${ }^{161}$ If the clause did not violate public policy, the claimant had to prove that in the circumstances of the case there was a good reason why there was a failure to comply. ${ }^{162}$ The court also held that in determining fairness, the relative equality or inequality of the bargaining position of the parties would be a relevant consideration. The court dismissed the appeal because in the circumstances the enforcement of the clause would not be contrary to public policy. ${ }^{163}$ The court concluded that the time bar clause was not manifestly unreasonable and unfair. As the contract was freely concluded, there was equal bargaining power between the parties even if the clause was not drawn to the attention of the other party.

The implication of this decision is that a contractual term will not be enforced if it is in conflict with constitutional values or if its implementation would result in unfairness or unreasonableness for being contrary to public policy even though the parties consented to it. ${ }^{164}$ Whether a contractual term is contrary to public policy is to be determined by the values which underlie the Constitution. ${ }^{165} \mathrm{~A}$ term in a contract that is contrary to the values protected by the Constitution is also contrary to public policy and will be unenforceable.

\section{Conclusion}

Under the common law the courts have always approached the issue of enforceability of exemption clauses on the basis of freedom of contract. The courts' approach has been influenced by the traditional view that issues of contracts should not be interfered with by the courts as they are an expression of free will by two consenting parties. The legislature

\footnotetext{
154 Alienation of Land Act 68 of 1981.

155 PN. Stoop "The Current Status of the Enforceability of Contractual Exemption Clauses for the Exclusion of Liability in the South African Law of Contract" (2008) 20 SA Merc LJ 506

${ }_{156}$ F Marx and A Govindjee 'Revisiting the interpretation of exemption clauses: Drifters Adventure Tours CC v Hircock 2007 (2) SA 83 (SCA) (2007) Obiter 632.

157 Section 39(2) of the Constitution states that when a court, tribunal or forum is developing the common law they must promote the spirit, purport and objects of the Bill of Rights.

1582007 (5) SA 323 (CC).

${ }^{159} / \mathrm{bid}$ per Ngcobo J at Paragraph 56.

160 ibid at Paragraph 57.

161 ibid at Paragraph 58.

$162 \mathrm{lbid}$ at Paragraph 59.

${ }_{163}$ ibid at paragraph 67

$164 \mathrm{Ibid}$, at paragraph 29 the court stated that 'what public policy is and whether a term is contrary to public policy must now be determined by reference to the values that underlie our constitutional democracy as given expression by the provisions of the Bill of Rights. Thus a term in a contract that is inimical to the values enshrined in our Constitution is contrary to public policy and is therefore not enforceable.

165 See Brisley v Drotsky 2002 (4) SA 1 (SCA) at paragraph 91 the court stated that 'In its modern guise 'public policy' is now rooted in our Constitution and the fundamental values it enshrines. These include human dignity, the achievement of equality and the advancement of human rights and freedoms, non-racialism and non-
} sexism." 
however has intervened to fill in the gap in situations where contracting parties in the weaker bargaining positions have been abused by their stronger counterparts through the Consumer Protection Act and the National Credit Act. It is now apparent that exemption clauses are no longer a prerogative of the contracting parties but public policy has now been entrenched into legislation to avoid harsh consequences which are usually brought by exemption clauses. The Consumer Protection Act creates a general standard of fairness by listing a variety of prohibited terms and terms which are presumed to be unfair for the benefit of consumers thereby altering the common law position. In consumer agreements, the language used should be clear, and where a risk activity is involved then that risk should be pointed out to the consumer.

The Constitution has had a significant impact on the use of exemption clauses. The principles of freedom of contract and sanctity of contract are no longer the only considerations. Principles of fairness, reasonableness and good faith have emerged with the coming of the Constitution and these have to be taken into account when courts decide on the validity of exemption clauses. The Consumer Protection Act, National Credit Act and Constitution mark a crucial turning point in the South African law of contract on the use and enforcement of exemption clauses. They try to make a balance or bring fairness between contracting parties.

\section{References}

Books

Christie, RH The Law of Contract in South Africa $6^{\text {th }}$ ed. (2011)

Devenish, GE A commentary of the South African bill of rights (1999)

Kerr, AJ The principles of the law of contract $6^{\text {th }}$ ed. (2002)

McQuoid- Mason, D Consumer Law in South Africa (1997)

Sharrock, RD Business Transactions Law $8^{\text {th }}$ ed. (2011)

Van Der Merwe S Contract: General Principles. $3^{\text {rd }}$ ed. (2007)

Van Eeden, E A Guide to the Consumer Protection Act (2009)

Journal articles

Bhana, D \& Pieterse, M "Towards a Reconciliation of Contract Law and Constitutional Values: Brisley and Afrox Revisited" (2005) 122 SALJ 865-895

Bhana, D "The law of contract and the Constitution: Napier v Barkhuizen SCA" (2007) 124 SALJ 269-280

De Stadler, E "If the consumer is king, suppliers are royal advisers" May (2008) Without Prejudice 26-28

Devenish, GE "The Interpretation and Validity of Exemption Clauses" February (1979) De Rebus 69-76

Du Plessis, MA "Enforcement and Execution Shortcomings of Consumer Courts" (2010) 22 SA Merc LJ 517-531

Du Preez, ML "The Consumer Protection Bill: A few preliminary comments" (2009) TSAR 1-26

Gouws, M "A Consumer's Right to Disclosure and Information: Comments on the Plain Language Provisions of the Consumer Protection Act" (2010) 22 SA Merc LJ 79-94

Harker, JR "Imposed Terms in Standard-form Contracts" (1981) 98 SALJ 15-21

Hopkins, S "Exemption clauses in contracts" June (2007) De Rebus 22-25

Kanamugire, JC "The future of standard form contracts in South Africa with particular reference to recent developments in the law" (2013) 4 MJSS 335-352

Kotz, H "Controlling Unfair Contract Terms: Options for Legislative Reform" (1986)103 SALJ 405-420

Lerm, $\mathrm{H}$ "Exclusionary clauses in medical contracts revisited" (2011) 74 THRHR 47-64

Lewis, J "Fairness in South African contract law" (2003) 120 SALJ 330- 351

Marx, F \& Govindjee A "Revisiting the Interpretation of Exemption Clauses: Drifters Adventures Tours CC v Hircock 2007 (2) SA 93 (SCA)" (2007) 28 Obiter $622-635$

McQuoid-Mason, D "Hospital exclusion clauses limiting liability for medical malpractice resulting in death or physical or psychological injury: what is the effect of the Consumer Protection Act?" (2012) 5 SAJBL 65- 68

Naudé, T \& Lubbe, G "Exemption clauses - a rethink occasioned by Afrox Healthcare Bpk v Strydom 2002 (6) SA 21 (SCA)" 122 (2005) SALJ 441-463

Naude, $T$ "The consumer's right to fair, reasonable and just terms under the new Consumer Protection Act in comparative perspective" (2009) 126 SALJ 505-536

Naude, T "Unfair contract terms legislation: The implications of why we need it for its formulation and application" (2006) 17 Stell LR 361-385

O'Brien, PH "The legality of contractual terms exempting a contractant from liability arising from his own or his servant's gross negligence or dolus" (2001) TSAR 597-603

Pretorius, CJ "Exemption clauses and Mistake: Mecurius Motors v Lopez (2008) 3 SA 572 (SCA)" (2010) 73 THRHR $491-502$

Pretorius, J "General principles of the law of contract: exemption clauses" (2007) Annual Survey of South Africa 472-9

Sharrock RD "The general principles of contract" (2009) Annual Survey of South Africa Law 510-529

Sharrock, RD "Judicial Control of Unfair Contract Terms: The Implications of the Consumer Protection Act" 201022 SA Merc LJ 295-325

Steyn, L "The inclusion of 'additional' terms or 'standard terms and conditions' in a contract: the significance of the 'ticket' cases, caveat subscriptor and the application of the reliance theory" (2004) 16 SA Merc LJ 106-112

Stoop, PN "The Current Status of the Enforceability of Contractual Exemption Clauses for the Exclusion of Liability in the South African Law of Contract (2008)" 20 SA Merc LJ 496-509

Sutherland, PJ "Ensuring Contractual Fairness in Consumer Contracts After Barkhuizen v Napier (2007) 5 SA 323 (CC) - Part 1" (2008) 3 Stell LR 390-414

Sutherland, PJ "Ensuring Contractual Fairness in Consumer Contracts After Barkhuizen v Napier (2007) 5 SA 323 (CC) - Part 2" (2009) 1 Stell LR 50-73

Tladi, DD "Breathing Constitutional values into the Law of contract: Freedom of contract and the constitution" (2002) 35 De Jure 306-317

Turpin, CC "Contract and imposed terms" (1956) 73 SALJ 144-158

Van Dorsten, JL "The Nature of a Contract and Exemption Clauses" (1986) 49 THRHR 189-207

Van Dorsten, JL "The Nature of Contract and Exemption Clauses" (1984) 47 THRHR 36-56 
Vos, A \& Reddy V "Welcome to the Maze" July 2011 Without Prejudice 30-31

Vrancken, P Tait M "Southern Africa can be a tough country for tourism service providers.....even with an exemption clause: Drifters Adventure Tours CC $v$ Hircock (2007) 1 All SA 133 (SCA)" (2008) 22 Speculum Juris 139-145

Statutes

Alienation of Land Act 68 of 1981

Constitution of the Republic of South Africa, 1996

Consumer Protection Act 68 of 2008

National Credit Act 34 of 2005

Cases

South Africa

Afrox Healthcare Bpk v Strydom 2002 (6) SA 21 (SCA)

Allen v Sixteen Stirling Investments (Pty) Ltd 1974 (4) SA 164 (D)

Barkhuizen v Napier 2007 (5) SA 323 (CC)

Bredenkamp v Standard Bank of South Africa Ltd 2010 (4) SA 468 (SCA)

Brink v Humphries \& Jewell (Pty) Ltd 2005 (2) SA 419 (SCA)

Brisely v Drotsky 2002 (4) SA 1 (SCA)

Burger v Central South African Railways 1903 TS 571

Cape Group Construction (Pty) Ltd v Government of the United Kingdom 2003 (5) SA 180 (SCA)

Cladall Roofing (Pty) Ltd v SS Profiling (Pty) Ltd [2010] 1 All SA 114 (SCA)

Consol Ltd v Twee Jonge Gezellen (Pty) Ltd 2002 (6) SA 256 (C)

Constantia Insurance Co Ltd v Compusource (Pty) Ltd 2005 (4) SA 345 (SCA)

D \& H Piping Systems (Pty) Ltd v Trans Hex Group Ltd and Another 2006 (3) SA 593 (SCA)

Dlovo v Brain Porter Motors Ltd t/a Port Motors Newlands 1994 (2) SA 518 (C)

Drifters Adventure Tours CC v Hircock 2007 (2) SA 83 (SCA)

Du Toit v Atkinson's Motors Bpk 1985 (2) SA 893 (A)

Durban's Water Wonderland (Pty) Ltd v Botha 1999 (1) SA 982 (SCA)

Elgin Brown \& Hamer (Pty) Ltd v Industrial Machinery Suppliers (Pty) Ltd 1993 (3) SA 424 (A)

Essa v Davaris 1947 (1) SA 753 (A)

First National Bank of SA Ltd v Rosenblum \& another 2001 (4) SA 189 (SCA)

Freddy Hirsch (Pty) Ltd v Chickenland (Pty) Ltd 2011 (4) SA 276 (SCA)

George v Fairmead (Pty) Ltd 1958 (2) SA 465 (A)

Goodman Brothers (Pty) Ltd v Rennies Group Ltd 1997 (4) SA 91 (W)

Government of the Republic of South Africa v Fibre Spinners \& Weavers 1978 (2) SA 794 (A)

Hartley v Pyramid Freight (Pty) Ltd t/a Sun Couriers 2007 (2) SA 599 (SCA)

Jacobs v Imperial Group (Pty) Ltd 2010 (2) All SA 540 (SCA)

Johannesburg Country Club v Stott 2004 (5) SA 511 (SCA)

Magna Alloys and Research SA (Pty) Ltd v Ellis 1984 (4) SA 874 (A)

Masstores (Pty) Ltd v Murray \& Roberts Construction and Another 2009 (1) All SA 146 (SCA)

Mercurius Motors v Lopez 2008 (3) SA 572 (SCA)

Micor Shipping (Pty) Ltd v Treger Golf and Sports (Pty) Ltd 1977 (2) SA 709 (W)

Morrison v Angelo Deep Gold Mines Ltd 1905 TS 775

Napier v Barkhuizen 2006 (4) SA 1 (SCA)

Sasfin v Beakes 1989 (1) SA 1 (A)

Sentrachem Ltd v Prinsloo 1997 (2) SA 1(A)

South African Railways \& Harbours v Lyle Shipping Co Ltd 1958 (3) SA 416 (A)

Standard Bank of SA Ltd v Essop 1997 (4) SA 569 (D)

Standard Bank of South Africa Ltd v Oneanate Investments (Pty) Ltd 1998 (1) SA 811 (SCA)

Swinburne v Newbee Investments (Pty) Ltd 2010 (5) SA 296 (KZD)

Van der Westhuizen v Arnold 2002 (6) SA 453 SCA

Vrystaat Motors v Henry Blignaut Motors 1996 (2) SA 448 (A)

Walker v Redhouse 2007 (4) All SA 1217 (SCA)

Weinberg v Oliver 1943 AD 181

Wells v South African Alumenite Co 1927 AD 69

United Kingdom

Anglo Saxon Petroleum Co Ltd v Adamastos Shipping Co Ltd 1957 (2) QB 233 (CA)

Printing and Numerical Registering Co v Simpson 1875 LR 19 EQ 462

Zimbabwe

Melfort Motors (Pty) Ltd v Finance Corpn of Rhodesia Ltd 1975 (3) SA 267 (RA)

Transport and Crane Hire Ltd v Hubert Davies \& Co Ltd 1991 (4) SA 150 (ZSC)

Law Commission Report

South African Law Reform Commission Project 47: Report on Unreasonable Stipulations in Contracts and the Rectification of Contracts (1998) 